\title{
Dual-Specificity Phosphatases in Neuroblastoma Cell Growth and Differentiation
}

\author{
Caroline E. Nunes-Xavier ${ }^{1,2, *}$, Laura Zaldumbide ${ }^{3}{ }^{(0)}$, Olaia Aurtenetxe ${ }^{1}$, \\ Ricardo López-Almaraz ${ }^{4}$, José I. López ${ }^{1,3}$ [D and Rafael Pulido ${ }^{1,5, *}$ \\ 1 Biomarkers in Cancer Unit, Biocruces-Bizkaia Health Research Institute, Barakaldo, Bizkaia 48903, Spain; \\ olaia.aurtenetxesaez@osakidetza.eus (O.A.); joseignacio.lopezfernandezdevillaverde@osakidetza.eus (J.I.L.) \\ 2 Department of Tumor Biology, Institute for Cancer Research, Oslo University Hospital HF Radiumhospitalet, \\ Oslo 0424, Norway \\ 3 Department of Pathology, Cruces University Hospital, University of the Basque Country (UPV/EHU), \\ Barakaldo, Bizkaia 48903, Spain; laura.zaldumbideduenas@osakidetza.eus \\ 4 Pediatric Oncology and Hematology, Cruces University Hospital, Barakaldo, Bizkaia 48903, Spain; \\ ricardo.lopezalmaraz@osakidetza.eus \\ 5 IKERBASQUE, Basque Foundation for Science, Bilbao 48011, Spain \\ * Correspondence: caroliten@gmail.com (C.E.N-X.); rpulidomurillo@gmail.com (R.P.)
}

Received: 13 February 2019; Accepted: 1 March 2019; Published: 7 March 2019

\begin{abstract}
Dual-specificity phosphatases (DUSPs) are important regulators of neuronal cell growth and differentiation by targeting proteins essential to neuronal survival in signaling pathways, among which the MAP kinases (MAPKs) stand out. DUSPs include the MAPK phosphatases (MKPs), a family of enzymes that directly dephosphorylate MAPKs, as well as the small-size atypical DUSPs, a group of low molecular-weight enzymes which display more heterogeneous substrate specificity. Neuroblastoma (NB) is a malignancy intimately associated with the course of neuronal and neuroendocrine cell differentiation, and constitutes the source of more common extracranial solid pediatric tumors. Here, we review the current knowledge on the involvement of MKPs and small-size atypical DUSPs in NB cell growth and differentiation, and discuss the potential of DUSPs as predictive biomarkers and therapeutic targets in human NB.
\end{abstract}

Keywords: neuroblastoma; neuronal differentiation; dual-specificity phosphatases; MAP kinases; MAP kinase phosphatases; atypical dual-specificity phosphatases

\section{Introduction}

Neuroblastoma (NB) is the most common malignancy diagnosed in the first year of life, with an average age at diagnosis of 18 months, and constitutes the most frequent extracranial solid tumor in infants, accounting for about $7 \%$ of total pediatric tumors. Although novel treatments have improved the survival of NB patients (about 80\% 5-year survival), the high-risk forms of NB are the major cause of pediatric cancer death, rendering about $15 \%$ of pediatric cancer mortality [1,2]. NB is a neuroendocrine embryonal malignancy that derives from developing sympathetic neuronal cells from the peripheral nervous system, primarily from the adrenal gland medulla (about $40 \%$ ), but also from the paraspinal sympathetic ganglia from the thorax, abdomen, neck, and pelvis [3-5]. NB arising from adrenal medulla display the worst prognosis, whereas those from the thorax, neck, and pelvis display better prognoses [6]. The current major criteria for staging and classification of NB cases are age, tumor histology subtype and differentiation, tumor spreading (about $20 \%$ of NB tumors are disseminated at diagnosis, with bone, bone marrow and liver as the more frequent metastatic niches), ploidy status and segmental chromosome aberrations, and MYCN (encoding an oncogenic transcription factor; about $25 \%$ of cases) and $A L K$ (encoding an oncogenic receptor tyrosine kinase (RTK); about $3 \%$ of cases) genes 
amplification (MYCN and ALK are physically linked at 2p24-2p23). Children with MYCN amplification regardless of age, those older than 12 months with disseminated tumors, or those older than 18 months with unfavorable histology, are considered to be part of the high-risk NB group (about $40 \%$ of cases). Very low-, low-, and intermediate-risk NB patients show a 5-year survival of $90-95 \%$, whereas high-risk NB patients show a 5-year survival of $40-50 \%$ [7-9]. The risk group determines the therapeutic treatment of NB patients, from observation or surgery alone for low-risk patients to multimodal therapy for high-risk patients. Multimodal therapy includes surgery, chemotherapy and radiotherapy, myeloablative therapy followed by bone marrow autologous transplantation, and immunotherapy and retinoic acid (RA)-based maintenance therapies. Current high-risk NB clinical trials are testing the efficacy of drugs targeting specific drivers of NB or major pro-oncogenic proteins. These include, among others, ALK and other RTKs, components of MYCN downstream pathways such as ornithine decarboxylase (ODC1), and components of the PI3K/AKT/mTOR and RAS-ERK1/2 MAPK signaling pathways [10-14].

Familial NB accounts for 1-2\% of NB cases, with two major genes showing germline mutations in association with the disease: the $A L K$ RTK gene, which is mainly expressed in the developing nervous system $[15,16]$; and the $P H O X 2 B$, encoding a transcription factor essential in neuronal differentiation and development of the autonomic nervous system, which is mutated in patients with congenital central hypoventilation syndrome (CCHS) [17]. Comprehensive analyses of the somatic mutational status of human cancers have revealed that the mutational burden of NB tumors is relatively low, compared with other cancers, a property which is shared by most pediatric tumors [18-21]. In addition, evidence for the existence of sporadic NB susceptibility genes has been recently obtained by several genome-wide association (GWA) studies on NB tumors, although the applicability of these findings has yet to be translated to the clinics [22-24]. In a GWA study, single nucleotide polymorphisms within the DUSP12 gene, which encodes a large-size atypical DUSP proposed to target MAPKs, were associated with low-risk NB $[25,26]$. In this review, we summarize the current knowledge on the role of MAPK phosphatases (MKPs) and related small-size atypical DUSPS in NB, and their potential as NB biomarker and drug targets.

\section{Neuroblastoma Cell Growth and Differentiation}

$\mathrm{NB}$ can be considered a neural crest-related developmental tissue disease in which alterations in neuronal differentiation, driven by the unbalanced action of pro-proliferative and pro-differentiation factors on the maturation and migration of neural crest cells and neuroblasts, play a fundamental etiologic role. Highly differentiated NB tumors have a favorable clinical outcome, and spontaneous regression linked to neuroblast apoptosis is frequent even in metastatic cases [5,27-29]. MYCN amplification, the major hallmark of high-risk NB, associates with poorly differentiated NB tumors [30-32], and signaling through ALK favors proliferation and/or survival depending on the maturity of the neural cells $[33,34]$. In addition, activation of the tyrosine kinase neurotrophin receptors TrkA and TrkB leads to apoptotic/differentiation neuroblast responses or to survival/proliferative effects, respectively [35-37]. Several animal models suitable to the study of NB differentiation and transformation have been generated, mainly centered in MYCN amplification and ALK hyperactivation [38,39]. NB cell differentiation can also be triggered in vitro by culturing NB cells in the presence of differentiation factors, such as retinoids (retinoic acid, RA), phorbol esters (phorbol 12-myristate 13-acetate, PMA), and neurotrophins (nerve growth factor, NGF; brain-derived neurotrophic factor, BDNF) $[40,41]$. Human and rodent cell lines commonly used to study NB cell differentiation include SH-SY5Y and other derivatives from the SK-N-SH cell line, IMR-32, SMS-KCNR (all NB; human), Neuro2A (NB; mouse), PC12 (pheochromocytoma; rat), and P19 (embryonic teratocarcinoma; mouse) cell lines, among others. Extensive experimental work using these model systems has provided a picture in which the major signaling pathways involved in the molecular effects of MYCN and ALK in NB are the RAS/MAPK, PI3K/AKT, and JAK/STAT pathways [41-44] (Figure 1). 


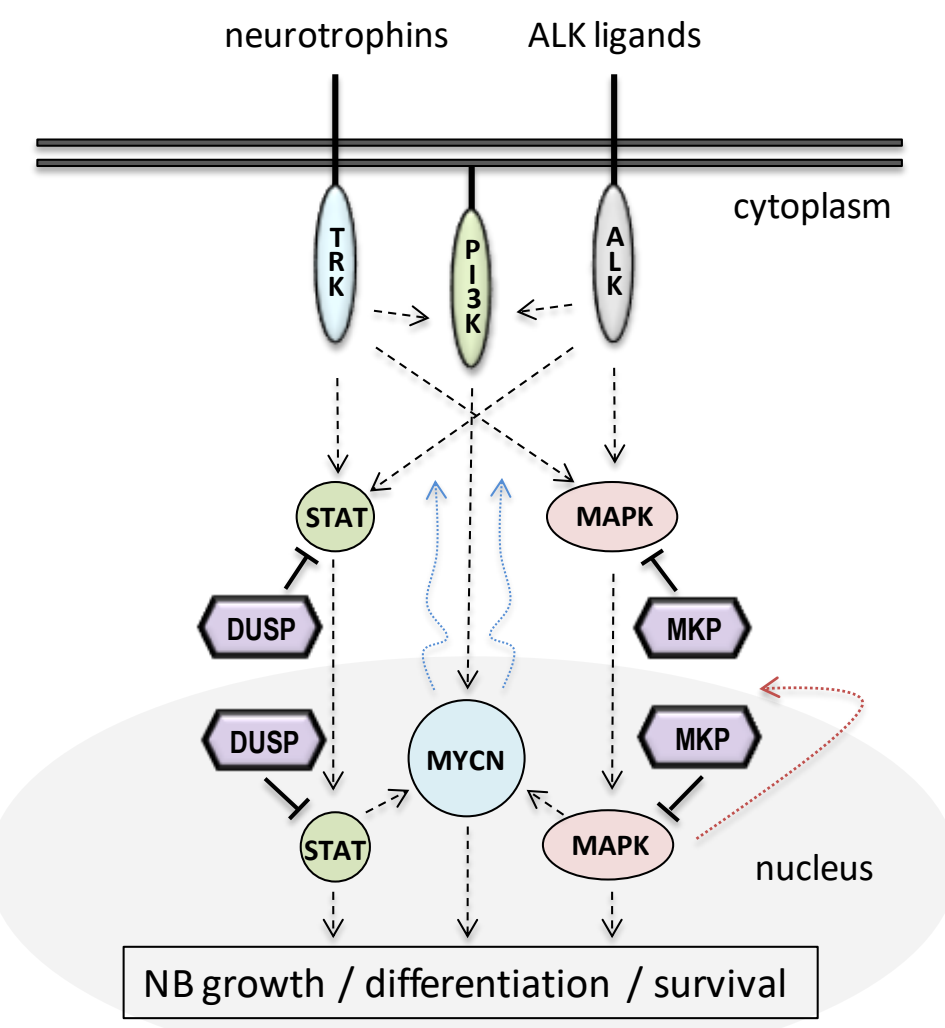

Figure 1. Schematic depiction of the major pathways involved in signaling through the ALK-MYCN axis in neuroblastoma (NB). ALK signals downstream mainly through the RAS-ERK1/2 MAP kinase (MAPK) pathway, as well as through the PI3K/AKT and JAK/STAT pathways, resulting in increased MYCN transcription and cell growth (straight dashed lines). Signaling through Trk neurotrophin receptors is also shown. MYCN transcriptional activity positively feeds the pathway by promoting $A L K$ transcription (curved blue dotted lines), whereas transcriptional activity mediated by the MAPK nuclear effectors negatively feed-back the MAPK pathways by promoting the transcription of MAPK phosphatases (MKP) genes (curved red dotted line). Straight solid lines indicate direct dephosphorylation of protein substrates by MKPs or by other dual-specificity phosphatases (DUSPs). Dephosphorylation of MAPKs by MKPs is well documented, whereas evidence on the dephosphorylation of STATs or Trks by other DUSPs is limited. See text for more details.

Genes related to the RAS-ERK1/2 MAPK pathway display somatic alterations in about 5\% of sporadic primary NB tumors, with a much higher percentage of alterations (especially in $A L K$, NRAS and NF1 genes) in relapsed NB samples obtained after chemotherapy [45-47]. This makes the RAS-ERK1/2 axis a potential responsive pathway for therapeutic intervention in NB. MEK1/2 or RAF-MEK1/2 pharmacological inhibitors displayed good inhibitory growth and survival effects, and decreased pERK1/2 levels, on NB cell lines with mutations in the RAS-ERK1/2 axis and high ERK1/2 activation under basal conditions [48-51]. Interestingly, combined use of a MEK1/2 inhibitor and RA resulted in increased differentiation and inhibitor sensitization of NB cells [52]. On the other hand, ALK-addicted NB cells responded to MEK1/2 inhibitors with an increase in survival and proliferation, which was associated with ERK5 activation through the PI3K/AKT pathway $[53,54]$. This highlights the importance of precise molecular segregation of NB patients before testing MEK1/2-inhibition in combination with other therapies, and illustrates the key role of distinct ERK kinases in mediating the efficacy of MEK1/2 inhibitors in NB. The influence of alterations in JNK and p38 MAPK pathways in NB cell growth has been investigated less. Higher sensitivity to apoptotic stimuli has mainly been reported in NB cell lines upon pharmacological inhibition of JNKs or p38s, although an anti-apoptotic 
outcome after inhibition of these MAPKs has also been reported [55-59] (Table 1). A complex scenario emerges in NB in which the specific contribution of the effectors from the distinct MAPK pathways may differentially drive NB cell growth, differentiation, and apoptosis, with variable consequences in the response to chemotherapies. As it has been proposed for other cell types, it is possible that a locally- and timely-regulated MAPK activation is critical for the response of NB cells to apoptotic or stress conditions. The interference of MAPK function by the inhibition of MAPK activators or inactivators (including phosphatase inactivators) is an open therapeutic possibility that deserves further exploration in NB.

Table 1. MKPs and small-size atypical DUSPs in neuroblastoma cell growth and differentiation.

\begin{tabular}{|c|c|c|}
\hline Gene/Protein & $\begin{array}{l}\text { MAPK Substrates } \\
\text { Localization }\end{array}$ & Alterations in NB Cell Lines and NB Tumors \\
\hline DUSP1/MKP1 & $\begin{array}{l}\text { JNK, p38 > ERK } \\
\text { Nuclear }\end{array}$ & $\begin{array}{l}\text {-SH-SY5Y cells: DUSP1 KD: } \downarrow \mathrm{H}_{2} \mathrm{O}_{2} \text {-induced apoptosis, } \\
\uparrow \text { pERK1/2 [60]; } \downarrow \text { DUSP1 mRNA upon AgNP treatment [61]; } \\
\uparrow \text { DUSP1 upon carbachol stimulation [62]. } \\
\text {-SK-N-SH and SK-N-BE cells: } \downarrow \text { DUSP1 protein in CD133+ } \\
\text { cells resistant to chemotherapy [63]. } \\
\text {-P19 cells: } \uparrow \text { DUSP1 protein upon RA differentiation [64]. } \\
\text {-GH4C1 neuroendocrine cells: } \uparrow \text { DUSP1 upon TRH and EGF } \\
\text { stimulation [65,66]. } \\
\text {-SMS-KCNR cells: } \uparrow \text { DUSP1 mRNA upon RA-induced } \\
\text { differentiation [67]. } \\
\text {-N1E-115 cells: } \uparrow \text { DUSP1 upon hypoxia/re-oxygenation; } \\
\text { DUSP1 KD: } \uparrow \text { pJNK, } \uparrow \text { neuronal death; } \\
D U S P 1 \text { OE: } \downarrow \text { pJNK, } \downarrow \text { neuronal death [68]. }\end{array}$ \\
\hline DUSP4/MKP2 & $\begin{array}{l}\text { ERK, JNK > p38 } \\
\text { Nuclear }\end{array}$ & $\begin{array}{l}\text {-SH-SY5Y cells: } \downarrow \text { DUSP4 mRNA upon AgNP treatment [61]. } \\
\text {-Mouse ESCs: DUSP4 KD: } \downarrow \text { neuronal differentiation, } \\
\uparrow \text { pERK1/2; } \uparrow \text { DUSP4 in RA-induced differentiation [69]. } \\
\text {-SH-SY5Y, KCNR cells: } \downarrow \text { DUSP4 upon RA-induced } \\
\text { differentiation [67]. } \\
\text {-SK-N-AS cells: } \downarrow \text { DUSP4 mRNA upon ALK inhibition, } \\
\uparrow \text { DUSP4 mRNA upon mutant ALK OE [70]. }\end{array}$ \\
\hline DUSP5 & $\begin{array}{l}\text { ERK } \\
\text { Nuclear }\end{array}$ & $\begin{array}{l}\text {-SiMa, Kelly, SH-SY5Y, CHP-134 cells: } \uparrow \text { DUSP5P1/DUSP5 } \\
\text { ratio compared to normal cells [71]. } \\
\text {-SH-SY5Y, SMS-KCNR, IMR-32 cells: } \uparrow \text { DUSP5 mRNA upon } \\
\text { RA-induced neuronal differentiation; SH-SY5Y cells: } \\
\uparrow \text { DUSP5 mRNA upon EGF and PMA stimulation; } \\
\text { DUSP5 KD: } \uparrow \text { proliferation [67]. } \\
\text {-SK-N-AS cells: } \downarrow \text { DUSP5 mRNA upon ALK inhibition, } \\
\uparrow \text { DUSP5 mRNA upon mutant ALK OE [70]. } \\
\text {-NB tumors: DUSP5 protein expression associated with } \\
\text { poor prognosis and pERK1/2 expression [67]. }\end{array}$ \\
\hline DUSP6/MKP3 & $\begin{array}{l}\text { ERK } \\
\text { Cytoplasmic }\end{array}$ & $\begin{array}{l}\text {-PC12 cells: } \uparrow \text { DUSP6 mRNA in FGF and NGF-mediated } \\
\text { neuronal differentiation [72-74]. } \\
\text {-P19 cells: } \uparrow \text { DUSP6 protein upon RA differentiation, } \\
\text { dependent on ERK1/2 activation [64]. } \\
\text {-SH-SY5Y, BE(2)-C cells: } \uparrow \text { DUSP6 mRNA upon RA-induced } \\
\text { differentiation; DUSP6 KD + RGS16 KD in SH-SY5Y cells: } \\
\downarrow \text { RA-mediated proliferation arrest [75]. } \\
\text {-IMR-32 cells: } \uparrow \text { DUSP6 mRNA upon RA-induced } \\
\text { differentiation [67]. } \\
\text {-SH-SY5Y cells: } \downarrow \text { DUSP6 protein upon } \mathrm{H}_{2} \mathrm{O}_{2} \text { stimulation [76]. } \\
\text {-SK-N-AS cells: } \downarrow \text { DUSP6 mRNA upon ALK inhibition, } \\
\uparrow \text { DUSP6 mRNA upon mutant ALK OE [70]. } \\
\text {-BE(2)-C, LAN-1 cells: } \downarrow \text { DUSP6 by a MYCN-SIRT1 complex [77]. }\end{array}$ \\
\hline
\end{tabular}


Table 1. Cont.

\begin{tabular}{|c|c|c|}
\hline Gene/Protein & $\begin{array}{l}\text { MAPK Substrates } 1 \\
\text { Localization }\end{array}$ & Alterations in NB Cell Lines and NB Tumors \\
\hline DUSP7/MKPX & $\begin{array}{l}\text { ERK } \\
\text { Cytoplasmic }\end{array}$ & $\begin{array}{l}\text {-NB tumors: Positive immunostaining, no clinical } \\
\text { associations [67]. }\end{array}$ \\
\hline DUSP8 & $\begin{array}{l}\text { JNK, p38 } \\
\text { Cytoplasmic/nuclear }\end{array}$ & $\begin{array}{l}\text {-Mouse J1 ESCs: } \uparrow \text { DUSP8 in RA-induced neuronal } \\
\text { differentiation [78]. }\end{array}$ \\
\hline DUSP9/MKP4 & $\begin{array}{l}\text { ERK }>\text { p38 } \\
\text { Cytoplasmic }\end{array}$ & $\begin{array}{l}\text {-Mouse J1 ESCs: } \downarrow \text { DUSP9 in RA-induced neuronal } \\
\text { differentiation [78]. } \\
\text {-SH-SY5Y, SMS-KCNR cells: } \downarrow \text { DUSP9 mRNA upon } \\
\text { RA-induced differentiation [67]. } \\
\text {-NB tumors: Mostly negative immunostaining, no } \\
\text { clinical associations [67]. }\end{array}$ \\
\hline DUSP10/MKP5 & $\begin{array}{l}\text { JNK, p38 } \\
\text { Cytoplasmic/nuclear }\end{array}$ & $\begin{array}{l}\text {-Mouse J1 ESCs: } \uparrow \text { DUSP10 in RA-induced neuronal } \\
\text { differentiation [78]. }\end{array}$ \\
\hline DUSP16/MKP7 & $\begin{array}{l}\text { JNK, p38 } \\
\text { Cytoplasmic/nuclear }\end{array}$ & $\begin{array}{l}\text {-DUSP16 -/- mice: hydrocephalus and brain overgrowth [79]. } \\
\text {-SMS-KCNR, IMR-32 cells: } \uparrow \text { DUSP16 mRNA upon } \\
\text { RA-induced differentiation [67]. }\end{array}$ \\
\hline DUSP3/VHR & $\begin{array}{l}\text { (ERK, JNK) } \\
\text { Cytoplasmic/nuclear }\end{array}$ & -SH-SY5Y cells: $\downarrow$ DUSP3 mRNA upon AgNP treatment [61]. \\
\hline DUSP13A/MDSP & Cytoplasmic & $\begin{array}{l}\text {-SK-N-SH cells: physical association with pro-apoptotic } \\
\text { ASK1, independent of phosphatase activity; } \\
\text { DUSP13A KD: } \downarrow \text { ASK1 kinase activity [80]. }\end{array}$ \\
\hline DUSP23/VHZ & $\begin{array}{l}\text { (ERK, JNK) } \\
\text { Cytoplasmic/nuclear }\end{array}$ & $\begin{array}{l}\text {-Mouse J1 ESCs: } \uparrow \text { DUSP23 in RA-induced neuronal } \\
\text { differentiation; DUSP23 KD: } \downarrow \text { neuronal differentiation, } \\
\uparrow \text { pp38, } \downarrow \text { pERK } 1 / 2, \downarrow \text { pJNK [78]. } \\
\text {-NB tumors: } \uparrow \text { Methylation in MYCN-amplified tumors, } \\
\downarrow \text { DUSP23 mRNA in patients with poor outcome [81]. }\end{array}$ \\
\hline DUSP26/MKP8 & $\begin{array}{l}\text { (p38) } \\
\text { Nuclear }\end{array}$ & $\begin{array}{l}\text {-Mouse J1 ESCs: } \uparrow \text { DUSP26 in RA-induced neuronal } \\
\text { differentiation [78]. } \\
\text {-PC12 cells: } \uparrow \text { DUSP26 mRNA in NGF-induced } \\
\text { differentiation; DUSP26 KD: } \uparrow \text { EGFR, } \uparrow \text { NGF-induced } \\
\text { differentiation; DUSP26 OE: } \downarrow \text { EGF-induced cell growth, } \\
\downarrow \text { NGF-induced differentiation, } \uparrow \text { cisplatin-induced } \\
\text { apoptosis, } \downarrow \text { pAKT, } \downarrow \text { EGFR }[82,83] \text {. } \\
\text {-Human NB cell lines: } \downarrow \text { DUSP26 mRNA compared to } \\
\text { normal adrenal gland [84]. } \\
\text {-IMR-32 cells: DUSP26 KD: } \uparrow \text { doxorubicin-induced } \\
\text { apoptosis, } \downarrow \text { proliferation, } \uparrow \text { pp53, } \uparrow \text { pp38; } \\
\text { SH-SY5Y cells: DUSP26 KD: } \downarrow \text { proliferation; } \\
\text { SK-N-SH cells: DUSP26 OE: } \downarrow \text { doxorubicin-induced } \\
\text { apoptosis, } \downarrow \text { pp53 [85,86]. } \\
\text {-NB tumors: } \uparrow \text { DUSP26 protein in high-risk NB tumors [85]. }\end{array}$ \\
\hline
\end{tabular}

\footnotetext{
${ }^{1}$ Note that substrate specificity towards MAPKs of small-size atypical DUSPs is debatable in some cases, and some effects on MAPK phosphorylation status have been reported to be likely mediated by scaffolding functions or by dephosphorylation of non-MAPK proteins. Abbreviations: AgNP—silver nanoparticles; ALK-anaplastic lymphoma kinase; EGF — epidermal growth factor; ESCs—embryonic stem cells; FGF-fibroblast growth factor; KD-knock-down; NB-neuroblastoma; NGF-nerve growth factor; OE-overexpression; PMA—phorbol 12-myristate 13-acetate; RA—retinoic acid; TRH—thyrotopin-releasing hormone; $\uparrow$-increase; $\downarrow$-decrease.
}

Finally, the involvement of the pro-survival PI3K/AKT and JAK/STAT pathways in NB has also been disclosed in a variety of studies, sometimes acting in coordination with MAPK activities; the inhibition of the effectors of these pathways as a NB therapeutic option is under scrutiny [44,87-90]. A functional ALK-MYCN axis operates in NB that positively controls cell growth through coordinated integration of these major signaling pathways [15,91,92] (Figure 1). 


\section{DUSPs in NB Cell Growth and Differentiation}

DUSPs constitute a heterogeneous group of non-transmembrane enzymes within the class I Cys-based protein tyrosine phosphatase (PTP) family. They have in common the presence of a single catalytic PTP domain, which in the members of several DUSP subfamilies, has the dual capability to dephosphorylate both Ser/Thr- and Tyr-phosphorylated residues (pSer/pThr, pTyr) in proteins. Enzymes from other DUSP subgroups, however, have RNA, lipids, or other biomolecules as their major substrates [93-96]. Here, we will focus on the MAPK phosphatase PTP subfamily (MKPs; 11 genes in humans) and the MKP-related small-size atypical DUSPs (15 genes in humans) (Figure 2), two groups of DUSPs with high potential as anti-cancer drug targets and as regulators of NB cell growth and differentiation $[97,98]$. With the exception of the phosphatase inactive MKP STYXL1, MKPs are specialized in the selective dephosphorylation of the Thr and Tyr regulatory residues from the distinct MAPKs (ERKs, p38s, and JNKs), a group of Ser/Thr kinases that shuttle between the cytoplasm and the nucleus and have major physiologic roles as modulators of cell growth, differentiation, and apoptosis upon changes in extracellular cues. Accordingly, alterations in the outcome of the MAPK pathways have a notable impact on human disease [99-103]. MKPs are composed of a catalytic DUSP-PTP domain and a regulatory MAPK-binding domain, which is essential to control the specificity in the binding and dephosphorylation of the distinct MAPKs (Figure 2A). In addition to their role in MAPK dephosphorylation, which results in MAPK catalytic inactivation, MKPs also directly regulate the nuclear-cytoplasmic shuttling of MAPKs upon the binding of their MAPK-binding domains [104-106]. MKPs expression, subcellular localization, and function is highly regulated during physiologic and pathologic processes, and MKPs gene expression is induced in many cases upon activation of the specific MAPK pathways under their regulation. In consequence, expression of different MKPs has been associated with several forms of human cancer [107-109]. Small-size atypical DUSPs lack the regulatory MAPK-binding domain and constitute small enzymes, among which DUSP3 is the one more intensively studied [110] (Figure 2A). Most of small-size atypical DUSPs dephosphorylate pSer/pThr and pTyr from proteins (including MAPKs, STATs, and RTKs), whereas some of these enzymes have as physiologic substrates other biomolecules or, in the case of the small-size atypical DUSP STYX, are phosphatase inactive [111,112].

The functional role of MKPs and small-size atypical DUSPs as physiologic MAPK inactivators advocates for their high potential as important players in NB cell growth and differentiation (Figure 1). In Figure 2B (upper and middle panels), the mRNA expression profiles of MKPs and small-size atypical DUSPs in the adrenal gland (the more common source of NB cells) and SH-SY5Y NB cells (the more studied human NB cell line) are shown. In Figure 2B (bottom panel), the changes in the mRNA expression of MKPs and small-size atypical DUSPs from three human NB cell lines (SH-SY5Y, SMS-KCNR, and IMR-32) undergoing retinoic acid (RA)-induced differentiation are shown. Different RA-regulated expression patterns of these genes can be observed, suggesting a complex and cell-specific rearrangement of DUSPs gene expression during NB cell differentiation. Following is an account on the expression and function of MKPs and small-size atypical DUSPs in NB, and a summary of the information is provided in Table 1. MKPs have been grouped according to amino acid sequence conservation, subcellular localization and substrate specificity, as reported in References $[98,113]$. 

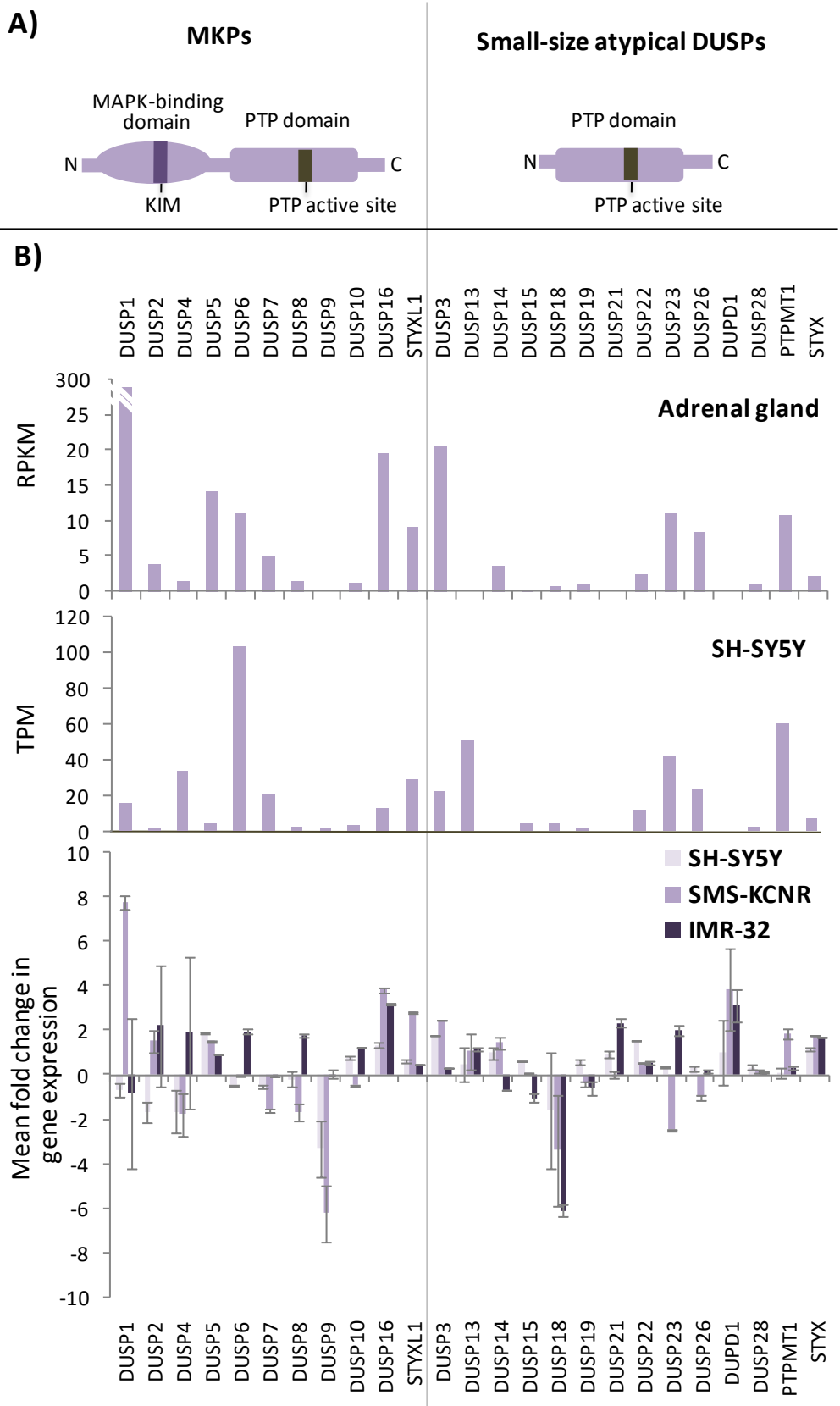

Figure 2. (A) Schematic depiction of the domain composition of MKPs and small-atypical DUSPs. KIM-kinase interaction motif; PTP-protein tyrosine phosphatase. (B) Upper panel: mRNA expression of MKPs and small-atypical DUSPs in adrenal gland. Data from GTEx (Genotype-Tissue Expression) data sets. RNA-seq data is reported as median RPKM (reads per kilobase per million reads mapped) (https://www.proteinatlas.org/). Middle panel: mRNA expression of MKPs and small-atypical DUSPs in SH-SY5Y human NB cells; data from the Human Protein Atlas. RNA-seq data is reported as median TPM (transcripts per kilobase of exon per million reads) (https:/ /www. proteinatlas.org/). Bottom panel: mRNA expression analysis of MKPs and small-atypical DUSPs from SH-SY5Y, SMS-KCNR, and IMR-32 human NB cell lines treated with retinoic acid (RA). Cell lines were kept untreated or were treated for 10 days with RA, mRNA was extracted and RT-qPCR was performed using a set of MKP and small-atypical DUSP primers, as described in Reference [67]. Relative mRNA expression values are shown in $\log _{2}$ as fold change $+\mathrm{SD}$ of treated cells versus untreated cells, from at least two independent experiments. Mean fold change above 2 or below -2 was considered significant. MKP mRNA expression data from bottom panel has been previously published [67]. 


\subsection{MKPs in NB Cell Growth and Differentiation}

\subsubsection{DUSP1, DUSP4, and DUSP5}

DUSP1 (MKP1), DUSP4 (MKP2), and DUSP5 constitute a group of highly transcriptionally inducible MKPs with nuclear localization and distinct MAPK substrate specificity. DUSP1 mainly dephosphorylates JNKs and p38s, whereas DUSP4 and DUSP5 are more specific for ERK1/2 as a substrate [114-116]. DUSP1 is the founder of the MKP family and displays ubiquitous tissue distribution. DUSP1 has been widely involved in human disease, including immunological, inflammatory and cardiovascular diseases, cancer, and developmental nervous system diseases [117-122]. In human NB cell lines, DUSP1 has been shown to facilitate apoptotic processes, suggesting a negative role for this MKP in NB cell survival. $\mathrm{H}_{2} \mathrm{O}_{2}$ treatment of SH-SY5Y cells triggered apoptosis which was accompanied by early reduction and late induction of DUSP1 protein content, in inverse correlation with pERK1/2 levels, and siRNA suppression of DUSP1 expression attenuated $\mathrm{H}_{2} \mathrm{O}_{2}$-induced cell death [60]. It would be important to determine the contribution of DUSP1 mRNA transcription to increasing DUSP1 levels in SH-SY5Y cells during long-term $\mathrm{H}_{2} \mathrm{O}_{2}$ treatment. In this regard, treatment of $\mathrm{SH}-\mathrm{SY} 5 \mathrm{Y}$ cells with silver nanoparticles (AgNP) inducing neuronal differentiation increased reactive oxygen species (ROS) generation, which was accompanied by decreased mRNA levels in several DUSPs, including DUSP1, and increased pAKT and pERK1/2 levels [61,123]. In addition, carbachol treatment of SH-SY5Y cells resulted in rapid ERK1/2 activation and increased nuclear DUSP1 protein content [62], whereas long-term stimulation with the differentiating agent RA caused up-regulation of DUSP1 mRNA in SMS-KCNR NB cells, but not in SH-SY5Y cells [67]. Interestingly, CD133+ stem-cell subpopulations from the human NB cell lines SK-N-SH and SK-N-BE displayed high resistance to pro-apoptotic chemotherapeutic agents, in association with DUSP1 protein low expression levels and high phosphoERK1/2 (pERK1/2) and phosphop38 (pp38) content, suggesting that DUSP1 expression, at least in some NB cell populations, may facilitate chemotherapy efficacy [63]. Treatment of $\mathrm{GH} 4 \mathrm{C} 1$ rat neuroendocrine cells with epidermal growth factor (EGF) or thyrotropin-releasing hormone (TRH) triggered DUSP1 mRNA translation [65], and P19 mouse embryonic stem cells (ESCs), induced to neuronal differentiation by RA treatment, also displayed increased nuclear DUSP1 protein content, coinciding with ERK1/2 inactivation [64]. On the other hand, an anti-apoptotic role has also been proposed for DUSP1 in NB cell lines in association with its action on JNKs. Hypoxia/re-oxygenation of N1E-115 mouse NB cells resulted in up-regulation of mRNA and protein DUSP1 levels, although JNK activation was not suppressed under these conditions. However, the siRNA knock-down of DUSP1 in N1E-115 cells induced to differentiate in the absence of serum resulted in increased JNK activation and apoptotic cell death, whereas DUSP1 over-expression caused the opposite effects [68]. These findings support the notion that the inhibitory action of nuclear DUSP1 on specific MAPKs at specific time-points could be a determinant of the survival of NB cells challenged with pro-apoptotic or pro-differentiation chemotherapies.

DUSP4 has been regarded as a potential tumor suppressor, as well as a promoter of chemotherapy resistance, in several human cancers [124-128]. DUSP4 expression augmented during RA-dependent neuronal differentiation of mouse ESCs, and shRNA silencing of DUSP4 expression in mouse ESCs decreased neuronal differentiation, in association with elevated pERK1/2 content and alterations in calcium homeostasis [69]. In contrast, DUSP4 mRNA was downregulated in SH-SY5Y cells subjected to neuronal differentiation by AgNP or RA [61,67]. In addition, human SK-N-AS NB cells subjected to pharmacologic ALK inhibition displayed mRNA downregulation of several ERK1/2 inactivators, including DUSP4, DUSP5, and DUSP6, whereas overexpression of hyperactive ALK caused upregulation of these MKPs [70]. This is suggestive of a negative ERK1/2 feed-back regulation, which could be operative during NB progression. Whether regulation of DUSP4 expression during NB cell growth is related to malignancy deserves further studies.

DUSP5, together with DUSP6, is an ERK1/2-specific MKP whose transcription is induced in an ERK1/2-dependent manner [129-132]. Some reports attribute tumor suppressor activities to DUSP5, and a dual role for this MKP in carcinogenesis, depending on the tissue and cellular context, 
has been proposed [109]. DUSP5 mRNA was upregulated on several human NB cell lines subjected to RA-induced differentiation. In SH-SY5Y cells, DUSP5 mRNA upregulation correlated with ERK1/2 activation conditions, illustrating that upregulation of ERK1/2-specific MKPs in NB cells is concomitant to the activation of ERK1/2 pathway, and DUSP5 siRNA knock-down resulted in increased cell proliferation. Importantly, high expression of DUSP5 protein was relatively frequent and also correlated with pERK1/2 expression in NB tumors, in association with poor patient prognosis, likely as a surrogate marker of ERK1/2 activation [67] (Figure 3). In another study, the expression in human cancer cells of DUSP5 and the DUSP5 pseudogene DUSP5P1 was compared, showing high ratios of DUSP5P1/DUSP5 expression in cancer cell lines, including NB cell lines, when compared to normal tissues [71]. In addition, DUSP5P1 expression has been found to be associated with poor prognosis in acute myeloid leukemia [133]. Further investigation is required to determine the role of DUSP5P1 in regulating DUSP5 function, and whether DUSP5P1 expression correlates with the prognosis of or tumor remission in NB.
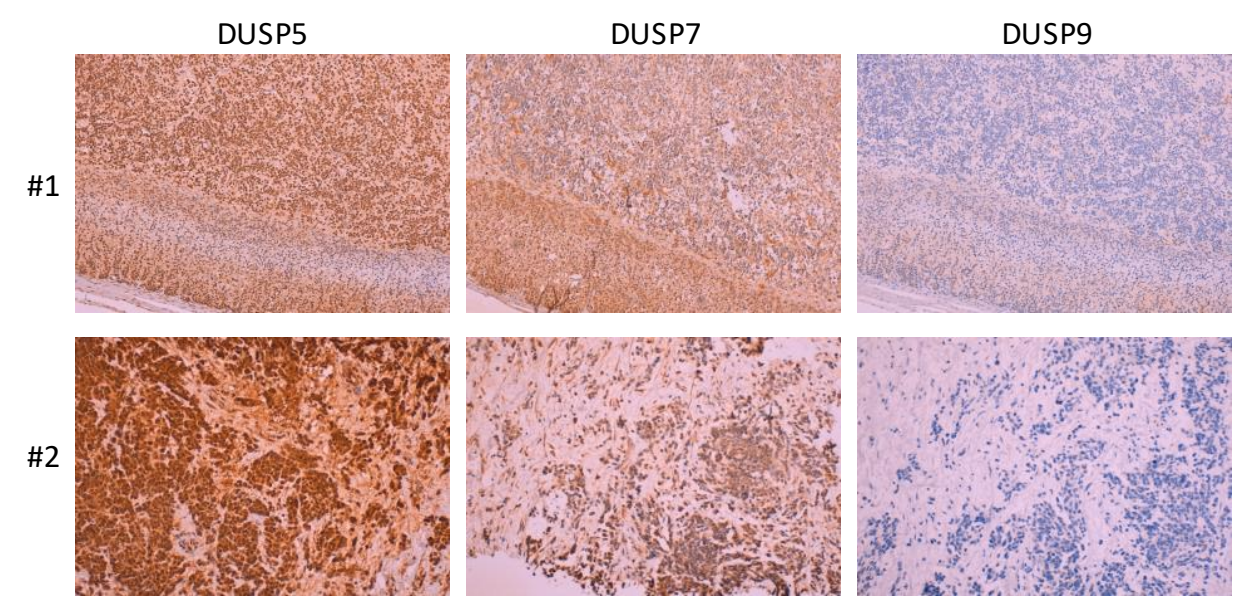

Figure 3. Immunostaining of selected MKPs from tissue sections from two NB tumors (\#1: Stage I, unknown MYCN status, low-risk; \#2: Stage IV, metastatic, MYCN amplification, high-risk). Representative staining patterns are shown. DUSP5 and DUSP7 mostly showed high-moderate immunoreactivity, whereas DUSP9 mostly displayed low immunoreactivity (magnification is $\times 100$ ). Immunostaining was performed as described in [67].

\subsubsection{DUSP6, DUSP7, and DUSP9}

DUSP6 (MKP3), DUSP7 (MKPX), and DUSP9 (MKP4) are cytoplasmic MKPs with specificity towards ERK1/2 dephosphorylation. Similar to DUSP5, DUSP6 is inducible by growth and differentiating agents that activate the ERK1/2 pathway [132,134,135], and DUSP6 is also reported to play a tissue-specific dual tumor suppressive or pro-oncogenic role $[105,136]$. DUSP6 mRNA is induced with NGF- or fibroblast growth factor (FGF)-mediated neuronal differentiation in PC12 rat pheochromocytoma cells [72-74], as well as with RA-mediated neuronal differentiation of SH-SY5Y, BE(2)-C, and IMR-32 human NB cells $[67,75]$. On the other hand, SH-SY5Y cells challenged with $\mathrm{H}_{2} \mathrm{O}_{2}$ displayed reduced DUSP6 protein levels, which was associated with a higher pERK1/ 2 content and cell death [76]. This effect is likely to be mediated by caspase-3 cleavage of DUSP6, as described for other human cancer cell lines [104]. Besides, co-silencing of DUSP6 and RGS16 (a negative regulator of Ras G proteins also induced by RA) in SH-SY5Y cells increased pERK1/2 levels and decreased the proliferation arrest caused by RA in these cells [75]. Differentiation of P19 mouse cells with RA also increased DUSP6 protein levels dependent on ERK1/2 activation. Interestingly, DUSP1 protein accumulation in these conditions was independent on ERK1/2 activation [64]. As mentioned, DUSP6 mRNA induction can be triggered in NB cells by signaling through hyperactive ALK [70], and DUSP6 transcription can be repressed by MYCN in BE(2)-C and LAN-1 NB cells [77]. Together, these findings illustrate the complexity in the negative and positive ERK1/2 regulatory feed-back loops that operate 
in NB cells by regulation of DUSP6 gene transcription and DUSP6 protein stability. They prompt further investigations of the potential of DUSP6 as a modulator of NB malignancy.

Expression of both DUSP7 and DUSP9 protein has been detected in NB tumor samples, although, in the case of DUSP9, with a low frequency [67] (Figure 3). Human SH-SY5Y and SMS-KCNR cells, as well as mouse J1 ESCs, displayed downregulation of DUSP9 mRNA upon RA-induced differentiation, which in the case of mouse J1 cells was confirmed at the protein level $[67,78]$.

\subsubsection{DUSP8, DUSP10, and DUSP16}

DUSP8, DUSP10 (MKP5), and DUSP16 (MKP7) are MKPs with substrate specificity towards JNKs and p38s MAPKs. These three MKPs are larger than the rest of the MKPs, with N- or C-terminal extensions in their amino acid sequences. DUSP10 and DUSP16 have been involved in autoimmunity and inflammation processes, and little is known about the physiological function of DUSP8. Interestingly, DUSP16 gene loss caused perinatal lethality in mice, associated with hydrocephalus, brain overgrowth by expansion of neural progenitors, and increased midbrain pp38 content [79]. RA treatment has been reported to upregulate DUSP8 and DUSP10 in mouse J1 ESCs, and DUSP16 mRNA in human NB cell lines $[67,78]$.

\subsection{Small-Size Atypical DUSPs in NB Cell Growth and Differentiation}

DUSP3 (VHR) is the prototype of small-size atypical DUSPs, and displays substrate specificity towards ERK1/2 and JNKs. However, some other proteins, including STAT5, FAK, growth factor receptors, and nuclear proteins regulating DNA damage repair, have been shown to be tyrosinedephosphorylated by DUSP3 and have been proposed as DUSP3 physiological substrates [110,137]. As mentioned for other MKPs, DUSP3 mRNA was upregulated in SH-SY5Y cells differentiated in the presence of AgNP [61], as well as on SH-SY5Y or SMS-KCNR cells differentiated by RA (Figure 2B, bottom panel), but the potential role of DUSP3 in NB cell growth and differentiation remains unexplored.

DUSP13A and DUSP13B are two small-size atypical DUSPs encoded in the same gene and generated by the use of alternative open reading frames, whose physiologic substrate specificity is poorly known [138]. DUSP13A (MDSP) was found to be a potential regulator of apoptosis in human SK-N-SH NB cells in a phosphatase-independent manner, by virtue of its physical association with the p38- and JNK-activator protein apoptosis signal-regulated kinase 1 (ASK1). The knock-down of DUSP13A decreased the phosphorylation and activation of ASK1 [80].

DUSP23 (VHZ) has been reported to affect MAPKs activation both by phosphatase-dependent and -independent mechanisms $[139,140]$, as well as the Ser- or Tyr-phosphorylation status of other proteins, including $\beta$-catenin and the transcription factor GCM1 [141,142]. DUSP23 mRNA and proteins were upregulated in RA-differentiated mouse ESCs, and siRNA knock-down of DUSP23 in these cells decreased neuronal differentiation, together with increased pp38 and decreased pERK $1 / 2$ and phosphoJNK (pJNK), likely by a combination of catalytic and scaffolding properties [78]. Noticeably, analysis of the methylation status of the DUSP23 gene in NB tumors revealed higher methylation in $M Y C N$-amplified tumors. In addition, DUSP23 mRNA was at lower levels in NB patients with poor outcomes, when compared to patients free of disease [81]. This suggests a tumor suppressive role for DUSP23 in NB. It would be important to analyze DUSP23 protein expression in these groups of NB patients.

DUSP26 (MKP8) was originally identified as a DUSP mainly expressed in embryonal cancers and displaying substrate specificity towards p38 in cells [143]. Subsequently, DUSP26 was also found in neuroendocrine tissues, and induced by NGF-stimulation in PC12 cells [82], as well as by RA in mouse ESCs [78]. DUSP26 overexpression in PC12 cells decreased EGFR and pAKT levels, which resulted in the suppression of NGF- and EGF-induced signaling. This effect was dependent on DUSP26 phosphatase activity, but was not associated with changes in MAPKs activation. Opposite consequences were observed with DUSP26 knock-down [82,83]. Additional studies in PC12 cells 
and in the zebrafish model sustain the possibility that DUSP26 could target for dephosphorylation specific receptor tyrosine kinases, including TrkA and FGFR1 [144]. In IMR-32 cells, DUSP26 has been proposed to increase N-cadherin-mediated cell-cell adhesion by dephosphorylation of the KIF3 motor complex component Kap3 [145]. A suppressive role of cell proliferation by DUSP26 targeting non-MAPK substrates has also been unveiled in epithelial cancer cells [84]. In contrast, an oncogenic role has been proposed for DUSP26 in human NB cells on the basis of DUSP26-mediated inhibition of p53 activity by specific Ser dephosphorylation and resistance to doxorubicin-induced apoptosis. Importantly, high-risk NB tumors displayed the highest levels of DUSP26 protein expression from a limited number of samples [85]. DUSP26 knock-down in SH-SY5Y cells inhibited cell growth in vitro and in xenograft mice, and this could be summarized by the pharmacological inhibition of DUSP26, which also increased phosphop53 (pp53) and pp38 levels [86]. Together, these results argue for both MAPK-dependent and -independent effects of DUSP26 in NB cell growth. It would be necessary to further define the oncogenic or tumor suppressive functions of DUSP26 in human NB before pointing to DUSP26 as a target for inhibition in these types of cancers.

\section{Concluding Remarks}

DUSPs have been proposed as cancer biomarkers in several human cancers, and recent advances in the understanding of the biology of DUSPs have made these enzymes potentially targetable molecules in cancer therapy: (1) DUSPs regulate cell growth, differentiation, and apoptosis through dephosphorylation of key effector proteins from major intracellular signaling pathways; (2) DUSPs present a well-defined catalytic mechanism towards well-defined substrates, especially those in the MAPK family; and (3) DUSPs activities can be efficiently repressed by small molecule inhibitors $[96,98,108,109,146]$. Signaling through the ALK-RAS-ERK1/2 MAPK pathway associates with NB tumor progression and relapse. Since the expression of some ERK1/2-specific MKPs, such as DUSP5 or DUSP6, is upregulated upon ERK1/2 activation, their expression in NB could be used as a surrogate marker of ALK and ERK1/2 activation status. In such scenario, inhibition of ERK1/2-MKPs is not desirable. Instead, increased activity of ERK1/2-MKPs would be therapeutically advantageous under the conditions of RAS-ERK1/2 pathway hyperactivation in NB, especially in high-risk NB committed to undifferentiation. On the other hand, the variable effects of JNK and p38 MAPKs on NB cell apoptosis endorse the possibility of a beneficial use of inhibitors of JNK- or p38-specific MKPs, such as DUSP1, DUSP8, DUSP10, or DUSP16, but only in NB cases in which the activity of JNKs or p38s favors tumor chemosensitivity. Finally, the possibility that specific small-atypical DUSPs directly target upstream components in the MAPK pathways, or receptor or effector proteins in other NB cell growth/survival pathways, such as Trks or STATs, deserves further exploration. A precise molecular definition of the pathways involved in NB cell growth dependence and drug resistance in the distinct groups of NB patients is desirable. This would help to bring into practice NB therapies based on MKPs or small-atypical DUSPs functional interference.

Author Contributions: conceptualization and writing-original draft preparation, C.E.N-X. and R.P.; writing-review and editing, C.E.N-X., L.Z., O.A., R.L.-A., J.I.L. and R.P.

Funding: This work was partially supported by the grants: BIO13/CI/001/BC from BIOEF (EITB maratoia), Basque Country, Spain; SAF2013-48812-R from the Ministerio de Educación y Ciencia (to R.P.), and SAF2016-79847-R from the Ministerio de Economía y Competitividad (Spain and Fondo Europeo de Desarrollo Regional) (to R.P. and J.I.L.); and 239813 from the Research Council of Norway (to C.E.N-X.).

Acknowledgments: We thank the Basque Country Biobank and the Basque Foundation for Science (Ikerbasque) for their help and support.

Conflicts of Interest: The authors declare no conflict of interest. 


\section{Abbreviations}

$\begin{array}{ll}\text { ALK } & \text { Anaplastic lymphoma kinase } \\ \text { BDNGF } & \text { Brain-derived neurotrophic factor } \\ \text { CCHS } & \text { Congenital central hypoventilation syndrome } \\ \text { DUSP } & \text { Dual-specificity phosphatase } \\ \text { EGFR } & \text { Epidermal growth factor receptor } \\ \text { ESC } & \text { Embryonic stem cell } \\ \text { FGFR } & \text { Fibroblast growth factor receptor } \\ \text { GWA } & \text { Genome-wide association } \\ \text { IFN } & \text { Interferon } \\ \text { KIM } & \text { Kinase interaction motif } \\ \text { MAPK } & \text { Mitogen-activated protein kinase } \\ \text { MKP } & \text { MAPK phosphatase } \\ \text { NB } & \text { Neuroblastoma } \\ \text { NGF } & \text { Nerve growth factor } \\ \text { PMA } & \text { Phorbol 12-myristate 13-acetate } \\ \text { PTP } & \text { Protein tyrosine phosphatase } \\ \text { RA } & \text { Retinoic acid } \\ \text { RTK } & \text { Receptor tyrosine kinase } \\ \text { TRH } & \text { Thyrotropin-releasing hormone }\end{array}$

\section{References}

1. Siegel, R.L.; Miller, K.D.; Jemal, A. Cancer statistics, 2018. CA Cancer J. Clin. 2018, 68, 7-30. [CrossRef] [PubMed]

2. Ward, E.; DeSantis, C.; Robbins, A.; Kohler, B.; Jemal, A. Childhood and adolescent cancer statistics, 2014. CA Cancer J. Clin. 2014, 64, 83-103. [CrossRef] [PubMed]

3. Maris, J.M.; Hogarty, M.D.; Bagatell, R.; Cohn, S.L. Neuroblastoma. Lancet 2007, 369, 2106-2120. [CrossRef]

4. Matthay, K.K.; Maris, J.M.; Schleiermacher, G.; Nakagawara, A.; Mackall, C.L.; Diller, L.; Weiss, W.A. Neuroblastoma. Nat. Rev. Dis. Primers 2016, 2, 16078. [CrossRef] [PubMed]

5. Tsubota, S.; Kadomatsu, K. Origin and initiation mechanisms of neuroblastoma. Cell Tissue Res. 2018, 372, 211-221. [CrossRef] [PubMed]

6. Vo, K.T.; Matthay, K.K.; Neuhaus, J.; London, W.B.; Hero, B.; Ambros, P.F.; Nakagawara, A.; Miniati, D.; Wheeler, K.; Pearson, A.D.; et al. Clinical, biologic, and prognostic differences on the basis of primary tumor site in neuroblastoma: A report from the international neuroblastoma risk group project. J. Clin. Oncol. 2014, 32, 3169-3176. [CrossRef] [PubMed]

7. Ahmed, A.A.; Zhang, L.; Reddivalla, N.; Hetherington, M. Neuroblastoma in children: Update on clinicopathologic and genetic prognostic factors. Pediatr. Hematol. Oncol. 2017, 34, 165-185. [CrossRef] [PubMed]

8. Park, J.R.; Bagatell, R.; London, W.B.; Maris, J.M.; Cohn, S.L.; Mattay, K.K.; Hogarty, M.; COG Neuroblastoma Committee. Children's Oncology Group's 2013 blueprint for research: Neuroblastoma. Pediatr. Blood Cancer 2013, 60, 985-993. [CrossRef] [PubMed]

9. Tolbert, V.P.; Matthay, K.K. Neuroblastoma: Clinical and biological approach to risk stratification and treatment. Cell Tissue Res. 2018, 372, 195-209. [CrossRef] [PubMed]

10. Amoroso, L.; Haupt, R.; Garaventa, A.; Ponzoni, M. Investigational drugs in phase II clinical trials for the treatment of neuroblastoma. Expert Opin. Investig. Drugs 2017, 26, 1281-1293. [CrossRef] [PubMed]

11. Berlanga, P.; Canete, A.; Castel, V. Advances in emerging drugs for the treatment of neuroblastoma. Expert Opin. Emerg. Drugs 2017, 22, 63-75. [CrossRef] [PubMed]

12. Greengard, E.G. Molecularly Targeted Therapy for Neuroblastoma. Children 2018, 5, 142. [CrossRef] [PubMed]

13. Johnsen, J.I.; Dyberg, C.; Fransson, S.; Wickstrom, M. Molecular mechanisms and therapeutic targets in neuroblastoma. Pharmacol. Res. 2018, 131, 164-176. [CrossRef] [PubMed]

14. Zage, P.E. Novel Therapies for Relapsed and Refractory Neuroblastoma. Children 2018, 5, 148. [CrossRef] [PubMed] 
15. Janoueix-Lerosey, I.; Lopez-Delisle, L.; Delattre, O.; Rohrer, H. The ALK receptor in sympathetic neuron development and neuroblastoma. Cell Tissue Res. 2018, 372, 325-337. [CrossRef] [PubMed]

16. Trigg, R.M.; Turner, S.D. ALK in Neuroblastoma: Biological and Therapeutic Implications. Cancers 2018, 10, 113. [CrossRef] [PubMed]

17. Maloney, M.A.; Kun, S.S.; Keens, T.G.; Perez, I.A. Congenital central hypoventilation syndrome: Diagnosis and management. Expert Rev. Respir. Med. 2018, 12, 283-292. [CrossRef] [PubMed]

18. Alexandrov, L.B.; Nik-Zainal, S.; Wedge, D.C.; Aparicio, S.A.; Behjati, S.; Biankin, A.V.; Bignell, G.R.; Bolli, N.; Borg, A.; Borresen-Dale, A.L.; et al. Signatures of mutational processes in human cancer. Nature 2013, 500, 415-421. [CrossRef] [PubMed]

19. Grobner, S.N.; Worst, B.C.; Weischenfeldt, J.; Buchhalter, I.; Kleinheinz, K.; Rudneva, V.A.; Johann, P.D.; Balasubramanian, G.P.; Segura-Wang, M.; Brabetz, S.; et al. The landscape of genomic alterations across childhood cancers. Nature 2018, 555, 321-327. [CrossRef] [PubMed]

20. Lawrence, M.S.; Stojanov, P.; Mermel, C.H.; Robinson, J.T.; Garraway, L.A.; Golub, T.R.; Meyerson, M.; Gabriel, S.B.; Lander, E.S.; Getz, G. Discovery and saturation analysis of cancer genes across 21 tumour types. Nature 2014, 505, 495-501. [CrossRef] [PubMed]

21. Ma, X.; Liu, Y.; Liu, Y.; Alexandrov, L.B.; Edmonson, M.N.; Gawad, C.; Zhou, X.; Li, Y.; Rusch, M.C.; Easton, J.; et al. Pan-cancer genome and transcriptome analyses of 1,699 paediatric leukaemias and solid tumours. Nature 2018, 555, 371-376. [CrossRef] [PubMed]

22. Barr, E.K.; Applebaum, M.A. Genetic Predisposition to Neuroblastoma. Children 2018, 5, 119. [CrossRef] [PubMed]

23. Ritenour, L.E.; Randall, M.P.; Bosse, K.R.; Diskin, S.J. Genetic susceptibility to neuroblastoma: Current knowledge and future directions. Cell Tissue Res. 2018, 372, 287-307. [CrossRef] [PubMed]

24. Tolbert, V.P.; Coggins, G.E.; Maris, J.M. Genetic susceptibility to neuroblastoma. Curr. Opin. Genet. Dev. 2017, 42, 81-90. [CrossRef] [PubMed]

25. Cho, S.S.L.; Han, J.; James, S.J.; Png, C.W.; Weerasooriya, M.; Alonso, S.; Zhang, Y. Dual-Specificity Phosphatase 12 Targets p38 MAP Kinase to Regulate Macrophage Response to Intracellular Bacterial Infection. Front. Immunol. 2017, 8, 1259. [CrossRef] [PubMed]

26. Nguyen le, B.; Diskin, S.J.; Capasso, M.; Wang, K.; Diamond, M.A.; Glessner, J.; Kim, C.; Attiyeh, E.F.; Mosse, Y.P.; Cole, K.; et al. Phenotype restricted genome-wide association study using a gene-centric approach identifies three low-risk neuroblastoma susceptibility Loci. PLoS Genet. 2011, 7, e1002026. [CrossRef] [PubMed]

27. Brodeur, G.M. Spontaneous regression of neuroblastoma. Cell Tissue Res. 2018, 372, 277-286. [CrossRef] [PubMed]

28. Mohlin, S.A.; Wigerup, C.; Pahlman, S. Neuroblastoma aggressiveness in relation to sympathetic neuronal differentiation stage. Semin. Cancer Biol. 2011, 21, 276-282. [CrossRef] [PubMed]

29. Tomolonis, J.A.; Agarwal, S.; Shohet, J.M. Neuroblastoma pathogenesis: Deregulation of embryonic neural crest development. Cell Tissue Res. 2018, 372, 245-262. [CrossRef] [PubMed]

30. Gherardi, S.; Valli, E.; Erriquez, D.; Perini, G. MYCN-mediated transcriptional repression in neuroblastoma: The other side of the coin. Front. Oncol. 2013, 3, 42. [CrossRef] [PubMed]

31. Huang, M.; Weiss, W.A. Neuroblastoma and MYCN. Cold Spring Harb. Perspect. Med. 2013, 3, a014415. [CrossRef] [PubMed]

32. Westermark, U.K.; Wilhelm, M.; Frenzel, A.; Henriksson, M.A. The MYCN oncogene and differentiation in neuroblastoma. Semin. Cancer Biol. 2011, 21, 256-266. [CrossRef] [PubMed]

33. Kramer, M.; Ribeiro, D.; Arsenian-Henriksson, M.; Deller, T.; Rohrer, H. Proliferation and Survival of Embryonic Sympathetic Neuroblasts by MYCN and Activated ALK Signaling. J. Neurosci. 2016, 36, 10425-10439. [CrossRef] [PubMed]

34. Reiff, T.; Huber, L.; Kramer, M.; Delattre, O.; Janoueix-Lerosey, I.; Rohrer, H. Midkine and Alk signaling in sympathetic neuron proliferation and neuroblastoma predisposition. Development 2011, 138, 4699-4708. [CrossRef] [PubMed]

35. Brodeur, G.M.; Minturn, J.E.; Ho, R.; Simpson, A.M.; Iyer, R.; Varela, C.R.; Light, J.E.; Kolla, V.; Evans, A.E. Trk receptor expression and inhibition in neuroblastomas. Clin. Cancer Res. 2009, 15, 3244-3250. [CrossRef] [PubMed]

36. Harel, L.; Costa, B.; Fainzilber, M. On the death Trk. Dev. Neurobiol. 2010, 70, 298-303. [CrossRef] [PubMed] 
37. Thiele, C.J.; Li, Z.; McKee, A.E. On Trk-The TrkB signal transduction pathway is an increasingly important target in cancer biology. Clin. Cancer Res. 2009, 15, 5962-5967. [CrossRef] [PubMed]

38. Casey, M.J.; Stewart, R.A. Zebrafish as a model to study neuroblastoma development. Cell Tissue Res. 2018, 372, 223-232. [CrossRef] [PubMed]

39. Kiyonari, S.; Kadomatsu, K. Neuroblastoma models for insights into tumorigenesis and new therapies. Expert Opin. Drug Discov. 2015, 10, 53-62. [CrossRef] [PubMed]

40. Edsjo, A.; Holmquist, L.; Pahlman, S. Neuroblastoma as an experimental model for neuronal differentiation and hypoxia-induced tumor cell dedifferentiation. Semin. Cancer Biol. 2007, 17, 248-256. [CrossRef] [PubMed]

41. Palmer, R.H.; Vernersson, E.; Grabbe, C.; Hallberg, B. Anaplastic lymphoma kinase: Signalling in development and disease. Biochem. J. 2009, 420, 345-361. [CrossRef] [PubMed]

42. Megison, M.L.; Gillory, L.A.; Beierle, E.A. Cell survival signaling in neuroblastoma. Anti-Cancer Agents Med. Chem. 2013, 13, 563-575. [CrossRef]

43. Roskoski, R., Jr. Anaplastic lymphoma kinase (ALK): Structure, oncogenic activation, and pharmacological inhibition. Pharmacol. Res. 2013, 68, 68-94. [CrossRef] [PubMed]

44. Stafman, L.L.; Beierle, E.A. Cell Proliferation in Neuroblastoma. Cancers 2016, 8, 13. [CrossRef] [PubMed]

45. Eleveld, T.F.; Oldridge, D.A.; Bernard, V.; Koster, J.; Daage, L.C.; Diskin, S.J.; Schild, L.; Bentahar, N.B.; Bellini, A.; Chicard, M.; et al. Relapsed neuroblastomas show frequent RAS-MAPK pathway mutations. Nat. Genet. 2015, 47, 864-871. [CrossRef] [PubMed]

46. Padovan-Merhar, O.M.; Raman, P.; Ostrovnaya, I.; Kalletla, K.; Rubnitz, K.R.; Sanford, E.M.; Ali, S.M.; Miller, V.A.; Mosse, Y.P.; Granger, M.P.; et al. Enrichment of Targetable Mutations in the Relapsed Neuroblastoma Genome. PLoS Genet. 2016, 12, e1006501. [CrossRef] [PubMed]

47. Pugh, T.J.; Morozova, O.; Attiyeh, E.F.; Asgharzadeh, S.; Wei, J.S.; Auclair, D.; Carter, S.L.; Cibulskis, K.; Hanna, M.; Kiezun, A.; et al. The genetic landscape of high-risk neuroblastoma. Nat. Genet. 2013, 45, $279-284$. [CrossRef] [PubMed]

48. Eppstein, A.C.; Sandoval, J.A.; Klein, P.J.; Woodruff, H.A.; Grosfeld, J.L.; Hickey, R.J.; Malkas, L.H.; Schmidt, C.M. Differential sensitivity of chemoresistant neuroblastoma subtypes to MAPK-targeted treatment correlates with ERK, p53 expression, and signaling response to U0126. J. Pediatr. Surg. 2006, 41, 252-259. [CrossRef] [PubMed]

49. Hart, L.S.; Rader, J.; Raman, P.; Batra, V.; Russell, M.R.; Tsang, M.; Gagliardi, M.; Chen, L.; Martinez, D.; Li, Y.; et al. Preclinical Therapeutic Synergy of MEK1/2 and CDK4/6 Inhibition in Neuroblastoma. Clin. Cancer Res. 2017, 23, 1785-1796. [CrossRef] [PubMed]

50. Tanaka, T.; Higashi, M.; Kimura, K.; Wakao, J.; Fumino, S.; Iehara, T.; Hosoi, H.; Sakai, T.; Tajiri, T. MEK inhibitors as a novel therapy for neuroblastoma: Their in vitro effects and predicting their efficacy. J. Pediatr. Surg. 2016, 51, 2074-2079. [CrossRef] [PubMed]

51. Woodfield, S.E.; Zhang, L.; Scorsone, K.A.; Liu, Y.; Zage, P.E. Binimetinib inhibits MEK and is effective against neuroblastoma tumor cells with low NF1 expression. BMC Cancer 2016, 16, 172. [CrossRef] [PubMed]

52. Singh, A.; Ruan, Y.; Tippett, T.; Narendran, A. Targeted inhibition of MEK1 by cobimetinib leads to differentiation and apoptosis in neuroblastoma cells. J. Exp. Clin. Cancer Res. CR 2015, 34, 104. [CrossRef] [PubMed]

53. Umapathy, G.; El Wakil, A.; Witek, B.; Chesler, L.; Danielson, L.; Deng, X.; Gray, N.S.; Johansson, M.; Kvarnbrink, S.; Ruuth, K.; et al. The kinase ALK stimulates the kinase ERK5 to promote the expression of the oncogene MYCN in neuroblastoma. Sci. Signal. 2014, 7, ra102. [CrossRef] [PubMed]

54. Umapathy, G.; Guan, J.; Gustafsson, D.E.; Javanmardi, N.; Cervantes-Madrid, D.; Djos, A.; Martinsson, T.; Palmer, R.H.; Hallberg, B. MEK inhibitor trametinib does not prevent the growth of anaplastic lymphoma kinase (ALK)-addicted neuroblastomas. Sci. Signal. 2017, 10, eaam755. [CrossRef] [PubMed]

55. Chen, K.; Lv, F.; Xu, G.; Zhang, M.; Wu, Y.; Wu, Z. Phosphoproteomics reveals ALK promote cell progress via RAS/ JNK pathway in neuroblastoma. Oncotarget 2016, 7, 75968-75980. [CrossRef] [PubMed]

56. Cheng, J.; Fan, Y.H.; Xu, X.; Zhang, H.; Dou, J.; Tang, Y.; Zhong, X.; Rojas, Y.; Yu, Y.; Zhao, Y.; et al. A small-molecule inhibitor of UBE2N induces neuroblastoma cell death via activation of p53 and JNK pathways. Cell Death Dis. 2014, 5, e1079. [CrossRef] [PubMed]

57. Dedoni, S.; Olianas, M.C.; Onali, P. Interferon-beta counter-regulates its own pro-apoptotic action by activating p38 MAPK signalling in human SH-SY5Y neuroblastoma cells. Apoptosis 2014, 19, 1509-1526. [CrossRef] [PubMed] 
58. Marengo, B.; De Ciucis, C.G.; Ricciarelli, R.; Furfaro, A.L.; Colla, R.; Canepa, E.; Traverso, N.; Marinari, U.M.; Pronzato, M.A.; Domenicotti, C. p38MAPK inhibition: A new combined approach to reduce neuroblastoma resistance under etoposide treatment. Cell Death Dis. 2013, 4, e589. [CrossRef] [PubMed]

59. Zhuang, J.; Li, Y.; Chi, Y. Role of p38 MAPK activation and mitochondrial cytochrome-c release in allicin-induced apoptosis in SK-N-SH cells. Anti-Cancer Drugs 2016, 27, 312-317. [CrossRef] [PubMed]

60. Kim, G.S.; Choi, Y.K.; Song, S.S.; Kim, W.K.; Han, B.H. MKP-1 contributes to oxidative stress-induced apoptosis via inactivation of ERK1/2 in SH-SY5Y cells. Biochem. Biophys. Res. Commun. 2005, 338, 1732-1738. [CrossRef] [PubMed]

61. Dayem, A.A.; Kim, B.; Gurunathan, S.; Choi, H.Y.; Yang, G.; Saha, S.K.; Han, D.; Han, J.; Kim, K.; Kim, J.H.; et al. Biologically synthesized silver nanoparticles induce neuronal differentiation of SH-SY5Y cells via modulation of reactive oxygen species, phosphatases, and kinase signaling pathways. Biotechnol. J. 2014, 9, 934-943. [CrossRef] [PubMed]

62. Rossler, O.G.; Henss, I.; Thiel, G. Transcriptional response to muscarinic acetylcholine receptor stimulation: Regulation of Egr-1 biosynthesis by ERK, Elk-1, MKP-1, and calcineurin in carbachol-stimulated human neuroblastoma cells. Arch. Biochem. Biophys. 2008, 470, 93-102. [CrossRef] [PubMed]

63. Vangipuram, S.D.; Wang, Z.J.; Lyman, W.D. Resistance of stem-like cells from neuroblastoma cell lines to commonly used chemotherapeutic agents. Pediatr. Blood Cancer 2010, 54, 361-368. [CrossRef] [PubMed]

64. Reffas, S.; Schlegel, W. Compartment-specific regulation of extracellular signal-regulated kinase (ERK) and c-Jun N-terminal kinase (JNK) mitogen-activated protein kinases (MAPKs) by ERK-dependent and non-ERK-dependent inductions of MAPK phosphatase (MKP)-3 and MKP-1 in differentiating P19 cells. Biochem. J. 2000, 352 Pt 3, 701-708.

65. Ryser, S.; Tortola, S.; Schlegel, W. Map kinase phosphatase-1 gene expression and regulation in neuroendocrine cells. J. Recept. Signal Transduct. Res. 2002, 22, 17-29. [CrossRef] [PubMed]

66. Ryser, S.; Tortola, S.; van Haasteren, G.; Muda, M.; Li, S.; Schlegel, W. MAP kinase phosphatase-1 gene transcription in rat neuroendocrine cells is modulated by a calcium-sensitive block to elongation in the first exon. J. Biol. Chem. 2001, 276, 33319-33327. [CrossRef] [PubMed]

67. Aurtenetxe, O.; Zaldumbide, L.; Erramuzpe, A.; Lopez, R.; Lopez, J.I.; Cortes, J.M.; Pulido, R.; Nunes-Xavier, C.E. DUSP5 expression associates with poor prognosis in human neuroblastoma. Exp. Mol. Pathol. 2018, 105, $272-278$. [CrossRef] [PubMed]

68. Koga, S.; Kojima, S.; Kishimoto, T.; Kuwabara, S.; Yamaguchi, A. Over-expression of map kinase phosphatase-1 (MKP-1) suppresses neuronal death through regulating JNK signaling in hypoxia/re-oxygenation. Brain Res. 2012, 1436, 137-146. [CrossRef] [PubMed]

69. Kim, S.Y.; Han, Y.M.; Oh, M.; Kim, W.K.; Oh, K.J.; Lee, S.C.; Bae, K.H.; Han, B.S. DUSP4 regulates neuronal differentiation and calcium homeostasis by modulating ERK1/2 phosphorylation. Stem Cells Dev. 2015, 24, 686-700. [CrossRef] [PubMed]

70. Lambertz, I.; Kumps, C.; Claeys, S.; Lindner, S.; Beckers, A.; Janssens, E.; Carter, D.R.; Cazes, A.; Cheung, B.B.; De Mariano, M.; et al. Upregulation of MAPK Negative Feedback Regulators and RET in Mutant ALK Neuroblastoma: Implications for Targeted Treatment. Clin. Cancer Res. 2015, 21, 3327-3339. [CrossRef] [PubMed]

71. Staege, M.S.; Muller, K.; Kewitz, S.; Volkmer, I.; Mauz-Korholz, C.; Bernig, T.; Korholz, D. Expression of dual-specificity phosphatase 5 pseudogene 1 (DUSP5P1) in tumor cells. PLoS ONE 2014, 9, e89577. [CrossRef] [PubMed]

72. Mourey, R.J.; Vega, Q.C.; Campbell, J.S.; Wenderoth, M.P.; Hauschka, S.D.; Krebs, E.G.; Dixon, J.E. A novel cytoplasmic dual specificity protein tyrosine phosphatase implicated in muscle and neuronal differentiation. J. Biol. Chem. 1996, 271, 3795-3802. [CrossRef] [PubMed]

73. Muda, M.; Boschert, U.; Dickinson, R.; Martinou, J.C.; Martinou, I.; Camps, M.; Schlegel, W.; Arkinstall, S. MKP-3, a novel cytosolic protein-tyrosine phosphatase that exemplifies a new class of mitogen-activated protein kinase phosphatase. J. Biol. Chem. 1996, 271, 4319-4326. [CrossRef] [PubMed]

74. Vician, L.; Basconcillo, R.; Herschman, H.R. Identification of genes preferentially induced by nerve growth factor versus epidermal growth factor in PC12 pheochromocytoma cells by means of representational difference analysis. J. Neurosci. Res. 1997, 50, 32-43. [CrossRef] 
75. Liu, T.; Bohlken, A.; Kuljaca, S.; Lee, M.; Nguyen, T.; Smith, S.; Cheung, B.; Norris, M.D.; Haber, M.; Holloway, A.J.; et al. The retinoid anticancer signal: Mechanisms of target gene regulation. Br. J. Cancer 2005, 93, 310-318. [CrossRef] [PubMed]

76. Mendell, A.L.; MacLusky, N.J. The testosterone metabolite 3alpha-androstanediol inhibits oxidative stress-induced ERK phosphorylation and neurotoxicity in SH-SY5Y cells through an MKP3/DUSP6-dependent mechanism. Neurosci. Lett. 2018, 696, 60-66. [CrossRef] [PubMed]

77. Marshall, G.M.; Liu, P.Y.; Gherardi, S.; Scarlett, C.J.; Bedalov, A.; Xu, N.; Iraci, N.; Valli, E.; Ling, D.; Thomas, W.; et al. SIRT1 promotes N-Myc oncogenesis through a positive feedback loop involving the effects of MKP3 and ERK on N-Myc protein stability. PLoS Genet. 2011, 7, e1002135. [CrossRef] [PubMed]

78. Kim, S.Y.; Oh, M.; Lee, K.S.; Kim, W.K.; Oh, K.J.; Lee, S.C.; Bae, K.H.; Han, B.S. Profiling analysis of protein tyrosine phosphatases during neuronal differentiation. Neurosci. Lett. 2016, 612, 219-224. [CrossRef] [PubMed]

79. Zega, K.; Jovanovic, V.M.; Vitic, Z.; Niedzielska, M.; Knaapi, L.; Jukic, M.M.; Partanen, J.; Friedel, R.H.; Lang, R.; Brodski, C. Dusp16 Deficiency Causes Congenital Obstructive Hydrocephalus and Brain Overgrowth by Expansion of the Neural Progenitor Pool. Front. Mol. Neurosci. 2017, 10, 372. [CrossRef] [PubMed]

80. Park, J.E.; Park, B.C.; Kim, H.A.; Song, M.; Park, S.G.; Lee, D.H.; Kim, H.J.; Choi, H.K.; Kim, J.T.; Cho, S. Positive regulation of apoptosis signal-regulating kinase 1 by dual-specificity phosphatase 13A. Cell. Mol. Life Sci. CMLS 2010, 67, 2619-2629. [CrossRef] [PubMed]

81. Caren, H.; Djos, A.; Nethander, M.; Sjoberg, R.M.; Kogner, P.; Enstrom, C.; Nilsson, S.; Martinsson, T. Identification of epigenetically regulated genes that predict patient outcome in neuroblastoma. BMC Cancer 2011, 11, 66. [CrossRef] [PubMed]

82. Wang, J.Y.; Lin, C.H.; Yang, C.H.; Tan, T.H.; Chen, Y.R. Biochemical and biological characterization of a neuroendocrine-associated phosphatase. J. Neurochem. 2006, 98, 89-101. [CrossRef] [PubMed]

83. Wang, J.Y.; Yang, C.H.; Yeh, C.L.; Lin, C.H.; Chen, Y.R. NEAP causes down-regulation of EGFR, subsequently induces the suppression of NGF-induced differentiation in PC12 cells. J. Neurochem. 2008, 107, 1544-1555. [CrossRef] [PubMed]

84. Patterson, K.I.; Brummer, T.; Daly, R.J.; O’Brien, P.M. DUSP26 negatively affects the proliferation of epithelial cells, an effect not mediated by dephosphorylation of MAPKs. Biochim. Biophys. Acta 2010, 1803, 1003-1012. [CrossRef] [PubMed]

85. Shang, X.; Vasudevan, S.A.; Yu, Y.; Ge, N.; Ludwig, A.D.; Wesson, C.L.; Wang, K.; Burlingame, S.M.; Zhao, Y.J.; Rao, P.H.; et al. Dual-specificity phosphatase 26 is a novel p53 phosphatase and inhibits p53 tumor suppressor functions in human neuroblastoma. Oncogene 2010, 29, 4938-4946. [CrossRef] [PubMed]

86. Shi, Y.; Ma, I.T.; Patel, R.H.; Shang, X.; Chen, Z.; Zhao, Y.; Cheng, J.; Fan, Y.; Rojas, Y.; Barbieri, E.; et al. NSC-87877 inhibits DUSP26 function in neuroblastoma resulting in p53-mediated apoptosis. Cell Death Dis. 2015, 6, e1841. [CrossRef] [PubMed]

87. Dedoni, S.; Olianas, M.C.; Onali, P. Interferon-beta induces apoptosis in human SH-SY5Y neuroblastoma cells through activation of JAK-STAT signaling and down-regulation of PI3K/Akt pathway. J. Neurochem. 2010, 115, 1421-1433. [CrossRef] [PubMed]

88. King, D.; Yeomanson, D.; Bryant, H.E. PI3King the lock: Targeting the PI3K/Akt/mTOR pathway as a novel therapeutic strategy in neuroblastoma. J. Pediatr. Hematol./Oncol. 2015, 37, 245-251. [CrossRef] [PubMed]

89. Sattu, K.; Hochgrafe, F.; Wu, J.; Umapathy, G.; Schonherr, C.; Ruuth, K.; Chand, D.; Witek, B.; Fuchs, J.; Li, P.K.; et al. Phosphoproteomic analysis of anaplastic lymphoma kinase (ALK) downstream signaling pathways identifies signal transducer and activator of transcription 3 as a functional target of activated ALK in neuroblastoma cells. FEBS J. 2013, 280, 5269-5282. [CrossRef] [PubMed]

90. Yan, S.; Li, Z.; Thiele, C.J. Inhibition of STAT3 with orally active JAK inhibitor, AZD1480, decreases tumor growth in Neuroblastoma and Pediatric Sarcomas In vitro and In vivo. Oncotarget 2013, 4, $433-445$. [CrossRef] [PubMed]

91. Hasan, M.K.; Nafady, A.; Takatori, A.; Kishida, S.; Ohira, M.; Suenaga, Y.; Hossain, S.; Akter, J.; Ogura, A.; Nakamura, Y.; et al. ALK is a MYCN target gene and regulates cell migration and invasion in neuroblastoma. Sci. Rep. 2013, 3, 3450. [CrossRef] [PubMed] 
92. Schonherr, C.; Ruuth, K.; Kamaraj, S.; Wang, C.L.; Yang, H.L.; Combaret, V.; Djos, A.; Martinsson, T.; Christensen, J.G.; Palmer, R.H.; et al. Anaplastic Lymphoma Kinase (ALK) regulates initiation of transcription of MYCN in neuroblastoma cells. Oncogene 2012, 31, 5193-5200. [CrossRef] [PubMed]

93. Alonso, A.; Pulido, R. The extended human PTPome: A growing tyrosine phosphatase family. FEBS J. 2016, 283, 1404-1429. [CrossRef] [PubMed]

94. Pulido, R.; Hooft van Huijsduijnen, R. Protein tyrosine phosphatases: Dual-specificity phosphatases in health and disease. FEBS J. 2008, 275, 848-866. [CrossRef] [PubMed]

95. Pulido, R.; Stoker, A.W.; Hendriks, W.J. PTPs emerge as PIPs: Protein tyrosine phosphatases with lipid-phosphatase activities in human disease. Hum. Mol. Genet. 2013, 22, R66-R76. [CrossRef] [PubMed]

96. Rios, P.; Nunes-Xavier, C.E.; Tabernero, L.; Kohn, M.; Pulido, R. Dual-specificity phosphatases as molecular targets for inhibition in human disease. Antioxid. Redox Signal. 2014, 20, 2251-2273. [CrossRef] [PubMed]

97. Huang, C.Y.; Tan, T.H. DUSPs, to MAP kinases and beyond. Cell Biosci. 2012, 2, 24. [CrossRef] [PubMed]

98. Nunes-Xavier, C.; Roma-Mateo, C.; Rios, P.; Tarrega, C.; Cejudo-Marin, R.; Tabernero, L.; Pulido, R. Dual-specificity MAP kinase phosphatases as targets of cancer treatment. Anti-Cancer Agents Med. Chem. 2011, 11, 109-132. [CrossRef]

99. Caunt, C.J.; Keyse, S.M. Dual-specificity MAP kinase phosphatases (MKPs): Shaping the outcome of MAP kinase signalling. FEBS J. 2013, 280, 489-504. [CrossRef] [PubMed]

100. Kim, E.K.; Choi, E.J. Pathological roles of MAPK signaling pathways in human diseases. Biochim. Biophys. Acta 2010, 1802, 396-405. [CrossRef] [PubMed]

101. Owens, D.M.; Keyse, S.M. Differential regulation of MAP kinase signalling by dual-specificity protein phosphatases. Oncogene 2007, 26, 3203-3213. [CrossRef] [PubMed]

102. Plotnikov, A.; Zehorai, E.; Procaccia, S.; Seger, R. The MAPK cascades: Signaling components, nuclear roles and mechanisms of nuclear translocation. Biochim. Biophys. Acta 2011, 1813, 1619-1633. [CrossRef] [PubMed]

103. Raman, M.; Chen, W.; Cobb, M.H. Differential regulation and properties of MAPKs. Oncogene 2007, 26, 3100-3112. [CrossRef] [PubMed]

104. Cejudo-Marín, R.; Tárrega, C.; Nunes-Xavier, C.E.; Pulido, R. Caspase-3 cleavage of DUSP6/MKP3 at the interdomain region generates active MKP3 fragments that regulate ERK1/2 subcellular localization and function. J. Mol. Biol. 2012, 420, 128-138. [CrossRef] [PubMed]

105. Kidger, A.M.; Rushworth, L.K.; Stellzig, J.; Davidson, J.; Bryant, C.J.; Bayley, C.; Caddye, E.; Rogers, T.; Keyse, S.M.; Caunt, C.J. Dual-specificity phosphatase 5 controls the localized inhibition, propagation, and transforming potential of ERK signaling. Proc. Natl. Acad. Sci. USA 2017, 114, E317-E326. [CrossRef] [PubMed]

106. Tarrega, C.; Rios, P.; Cejudo-Marin, R.; Blanco-Aparicio, C.; van den Berk, L.; Schepens, J.; Hendriks, W.; Tabernero, L.; Pulido, R. ERK2 shows a restrictive and locally selective mechanism of recognition by its tyrosine phosphatase inactivators not shared by its activator MEK1. J. Biol. Chem. 2005, 280, 37885-37894. [CrossRef] [PubMed]

107. Kidger, A.M.; Keyse, S.M. The regulation of oncogenic Ras/ERK signalling by dual-specificity mitogen activated protein kinase phosphatases (MKPs). Semin. Cell Dev. Biol. 2016, 50, 125-132. [CrossRef] [PubMed]

108. Low, H.B.; Zhang, Y. Regulatory Roles of MAPK Phosphatases in Cancer. Immune Netw. 2016, 16, 85-98. [CrossRef] [PubMed]

109. Seternes, O.M.; Kidger, A.M.; Keyse, S.M. Dual-specificity MAP kinase phosphatases in health and disease. Biochim. Biophys. Acta. Mol. Cell Res. 2019, 1866, 124-143. [CrossRef] [PubMed]

110. Pavic, K.; Duan, G.; Kohn, M. VHR/DUSP3 phosphatase: Structure, function and regulation. FEBS J. 2015, 282, 1871-1890. [CrossRef] [PubMed]

111. Alonso, A.; Nunes-Xavier, C.E.; Bayon, Y.; Pulido, R. The Extended Family of Protein Tyrosine Phosphatases. Methods Mol. Biol. 2016, 1447, 1-23. [CrossRef] [PubMed]

112. Patterson, K.I.; Brummer, T.; O’Brien, P.M.; Daly, R.J. Dual-specificity phosphatases: Critical regulators with diverse cellular targets. Biochem. J. 2009, 418, 475-489. [CrossRef] [PubMed]

113. Dickinson, R.J.; Keyse, S.M. Diverse physiological functions for dual-specificity MAP kinase phosphatases. J. Cell Sci. 2006, 119, 4607-4615. [CrossRef] [PubMed]

114. Kutty, R.G.; Talipov, M.R.; Bongard, R.D.; Lipinski, R.A.J.; Sweeney, N.L.; Sem, D.S.; Rathore, R.; Ramchandran, R. Dual Specificity Phosphatase 5-Substrate Interaction: A Mechanistic Perspective. Compr. Physiol. 2017, 7, 1449-1461. [CrossRef] [PubMed] 
115. Lawan, A.; Shi, H.; Gatzke, F.; Bennett, A.M. Diversity and specificity of the mitogen-activated protein kinase phosphatase-1 functions. Cell. Mol. Life Sci. CMLS 2013, 70, 223-237. [CrossRef] [PubMed]

116. Lawan, A.; Torrance, E.; Al-Harthi, S.; Shweash, M.; Alnasser, S.; Neamatallah, T.; Schroeder, J.; Plevin, R. MKP-2: Out of the DUSP-bin and back into the limelight. Biochem. Soc. Trans. 2012, 40, 235-239. [CrossRef] [PubMed]

117. Collins, L.M.; Downer, E.J.; Toulouse, A.; Nolan, Y.M. Mitogen-Activated Protein Kinase Phosphatase (MKP)-1 in Nervous System Development and Disease. Mol. Neurobiol. 2015, 51, 1158-1167. [CrossRef] [PubMed]

118. Li, C.Y.; Yang, L.C.; Guo, K.; Wang, Y.P.; Li, Y.G. Mitogen-activated protein kinase phosphatase-1: A critical phosphatase manipulating mitogen-activated protein kinase signaling in cardiovascular disease (review). Int. J. Mol. Med. 2015, 35, 1095-1102. [CrossRef] [PubMed]

119. Moosavi, S.M.; Prabhala, P.; Ammit, A.J. Role and regulation of MKP-1 in airway inflammation. Respir. Res. 2017, 18, 154. [CrossRef] [PubMed]

120. Ralph, J.A.; Morand, E.F. MAPK phosphatases as novel targets for rheumatoid arthritis. Expert Opin. Ther. Targets 2008, 12, 795-808. [CrossRef] [PubMed]

121. Shen, J.; Zhang, Y.; Yu, H.; Shen, B.; Liang, Y.; Jin, R.; Liu, X.; Shi, L.; Cai, X. Role of DUSP1/MKP1 in tumorigenesis, tumor progression and therapy. Cancer Med. 2016, 5, 2061-2068. [CrossRef] [PubMed]

122. Wancket, L.M.; Frazier, W.J.; Liu, Y. Mitogen-activated protein kinase phosphatase (MKP)-1 in immunology, physiology, and disease. Life Sci. 2012, 90, 237-248. [CrossRef] [PubMed]

123. Abdal Dayem, A.; Lee, S.B.; Choi, H.Y.; Cho, S.G. Silver Nanoparticles: Two-Faced Neuronal DifferentiationInducing Material in Neuroblastoma (SH-SY5Y) Cells. Int. J. Mol. Sci. 2018, 19, 1470. [CrossRef] [PubMed]

124. Chen, M.; Zhang, J.; Berger, A.H.; Diolombi, M.S.; Ng, C.; Fung, J.; Bronson, R.T.; Castillo-Martin, M.; Thin, T.H.; Cordon-Cardo, C.; et al. Compound haploinsufficiency of Dok2 and Dusp4 promotes lung tumorigenesis. J. Clin. Investig. 2018, 129, 215-222. [CrossRef] [PubMed]

125. Hijiya, N.; Tsukamoto, Y.; Nakada, C.; Tung Nguyen, L.; Kai, T.; Matsuura, K.; Shibata, K.; Inomata, M.; Uchida, T.; Tokunaga, A.; et al. Genomic Loss of DUSP4 Contributes to the Progression of Intraepithelial Neoplasm of Pancreas to Invasive Carcinoma. Cancer Res. 2016, 76, 2612-2625. [CrossRef] [PubMed]

126. Ichimanda, M.; Hijiya, N.; Tsukamoto, Y.; Uchida, T.; Nakada, C.; Akagi, T.; Etoh, T.; Iha, H.; Inomata, M.; Takekawa, M.; et al. Downregulation of dual-specificity phosphatase 4 enhances cell proliferation and invasiveness in colorectal carcinomas. Cancer Sci. 2018, 109, 250-258. [CrossRef] [PubMed]

127. Kang, X.; Li, M.; Zhu, H.; Lu, X.; Miao, J.; Du, S.; Xia, X.; Guan, W. DUSP4 promotes doxorubicin resistance in gastric cancer through epithelial-mesenchymal transition. Oncotarget 2017, 8, 94028-94039. [CrossRef] [PubMed]

128. Menyhart, O.; Budczies, J.; Munkacsy, G.; Esteva, F.J.; Szabo, A.; Miquel, T.P.; Gyorffy, B. DUSP4 is associated with increased resistance against anti-HER2 therapy in breast cancer. Oncotarget 2017, 8, 77207-77218. [CrossRef] [PubMed]

129. Buffet, C.; Hecale-Perlemoine, K.; Bricaire, L.; Dumont, F.; Baudry, C.; Tissier, F.; Bertherat, J.; Cochand-Priollet, B.; Raffin-Sanson, M.L.; Cormier, F.; et al. DUSP5 and DUSP6, two ERK specific phosphatases, are markers of a higher MAPK signaling activation in BRAF mutated thyroid cancers. PLoS ONE 2017, 12, e0184861. [CrossRef] [PubMed]

130. Higa, T.; Takahashi, H.; Higa-Nakamine, S.; Suzuki, M.; Yamamoto, H. Up-regulation of DUSP5 and DUSP6 by gonadotropin-releasing hormone in cultured hypothalamic neurons, GT1-7 cells. Biomed. Res. 2018, 39, 149-158. [CrossRef] [PubMed]

131. Kucharska, A.; Rushworth, L.K.; Staples, C.; Morrice, N.A.; Keyse, S.M. Regulation of the inducible nuclear dual-specificity phosphatase DUSP5 by ERK MAPK. Cell. Signal. 2009, 21, 1794-1805. [CrossRef] [PubMed]

132. Nunes-Xavier, C.E.; Tárrega, C.; Cejudo-Marín, R.; Frijhoff, J.; Sandin, A.; Ostman, A.; Pulido, R. Differential up-regulation of MAP kinase phosphatases MKP3/DUSP6 and DUSP5 by Ets2 and c-Jun converge in the control of the growth arrest versus proliferation response of MCF-7 breast cancer cells to phorbol ester. J. Biol. Chem. 2010, 285, 26417-26430. [CrossRef] [PubMed]

133. Zhou, L.Y.; Yin, J.Y.; Tang, Q.; Zhai, L.L.; Zhang, T.J.; Wang, Y.X.; Yang, D.Q.; Qian, J.; Lin, J.; Deng, Z.Q. High expression of dual-specificity phosphatase 5 pseudogene 1 (DUSP5P1) is associated with poor prognosis in acute myeloid leukemia. Int. J. Clin. Exp. Pathol. 2015, 8, 16073-16080. [PubMed] 
134. Ekerot, M.; Stavridis, M.P.; Delavaine, L.; Mitchell, M.P.; Staples, C.; Owens, D.M.; Keenan, I.D.; Dickinson, R.J.; Storey, K.G.; Keyse, S.M. Negative-feedback regulation of FGF signalling by DUSP6/MKP-3 is driven by ERK1/2 and mediated by Ets factor binding to a conserved site within the DUSP6/MKP-3 gene promoter. Biochem. J. 2008, 412, 287-298. [CrossRef] [PubMed]

135. Li, C.; Scott, D.A.; Hatch, E.; Tian, X.; Mansour, S.L. Dusp6 (Mkp3) is a negative feedback regulator of FGF-stimulated ERK signaling during mouse development. Development 2007, 134, 167-176. [CrossRef] [PubMed]

136. Ahmad, M.K.; Abdollah, N.A.; Shafie, N.H.; Yusof, N.M.; Razak, S.R.A. Dual-specificity phosphatase 6 (DUSP6): A review of its molecular characteristics and clinical relevance in cancer. Cancer Biol. Med. 2018, 15, 14-28. [CrossRef] [PubMed]

137. Monteiro, L.F.; Ferruzo, P.Y.M.; Russo, L.C.; Farias, J.O.; Forti, F.L. DUSP3/VHR: A Druggable Dual Phosphatase for Human Diseases. Rev. Physiol. Biochem. Pharmacol. 2018. [CrossRef]

138. Chen, H.H.; Luche, R.; Wei, B.; Tonks, N.K. Characterization of two distinct dual specificity phosphatases encoded in alternative open reading frames of a single gene located on human chromosome 10q22.2. J. Biol. Chem. 2004, 279, 41404-41413. [CrossRef] [PubMed]

139. Takagaki, K.; Satoh, T.; Tanuma, N.; Masuda, K.; Takekawa, M.; Shima, H.; Kikuchi, K. Characterization of a novel low-molecular-mass dual-specificity phosphatase-3 (LDP-3) that enhances activation of JNK and p38. Biochem. J. 2004, 383, 447-455. [CrossRef] [PubMed]

140. Wu, Q.; Li, Y.; Gu, S.; Li, N.; Zheng, D.; Li, D.; Zheng, Z.; Ji, C.; Xie, Y.; Mao, Y. Molecular cloning and characterization of a novel dual-specificity phosphatase 23 gene from human fetal brain. Int. J. Biochem. Cell Biol. 2004, 36, 1542-1553. [CrossRef] [PubMed]

141. Gallegos, L.L.; Ng, M.R.; Sowa, M.E.; Selfors, L.M.; White, A.; Zervantonakis, I.K.; Singh, P.; Dhakal, S.; Harper, J.W.; Brugge, J.S. A protein interaction map for cell-cell adhesion regulators identifies DUSP23 as a novel phosphatase for beta-catenin. Sci. Rep. 2016, 6, 27114. [CrossRef] [PubMed]

142. Lin, F.Y.; Chang, C.W.; Cheong, M.L.; Chen, H.C.; Lee, D.Y.; Chang, G.D.; Chen, H. Dual-specificity phosphatase 23 mediates GCM1 dephosphorylation and activation. Nucleic Acids Res. 2011, 39, 848-861. [CrossRef] [PubMed]

143. Vasudevan, S.A.; Skoko, J.; Wang, K.; Burlingame, S.M.; Patel, P.N.; Lazo, J.S.; Nuchtern, J.G.; Yang, J. MKP-8, a novel MAPK phosphatase that inhibits p38 kinase. Biochem. Biophys. Res. Commun. 2005, 330, 511-518. [CrossRef] [PubMed]

144. Yang, C.H.; Yeh, Y.J.; Wang, J.Y.; Liu, Y.W.; Chen, Y.L.; Cheng, H.W.; Cheng, C.M.; Chuang, Y.J.; Yuh, C.H.; Chen, Y.R. NEAP/DUSP26 suppresses receptor tyrosine kinases and regulates neuronal development in zebrafish. Sci. Rep. 2017, 7, 5241. [CrossRef] [PubMed]

145. Tanuma, N.; Nomura, M.; Ikeda, M.; Kasugai, I.; Tsubaki, Y.; Takagaki, K.; Kawamura, T.; Yamashita, Y.; Sato, I.; Sato, M.; et al. Protein phosphatase Dusp26 associates with KIF3 motor and promotes $\mathrm{N}$-cadherin-mediated cell-cell adhesion. Oncogene 2009, 28, 752-761. [CrossRef] [PubMed]

146. Lazo, J.S.; McQueeney, K.E.; Burnett, J.C.; Wipf, P.; Sharlow, E.R. Small molecule targeting of PTPs in cancer. Int. J. Biochem. Cell Biol. 2018, 96, 171-181. [CrossRef] [PubMed]

(C) 2019 by the authors. Licensee MDPI, Basel, Switzerland. This article is an open access article distributed under the terms and conditions of the Creative Commons Attribution (CC BY) license (http:/ / creativecommons.org/licenses/by/4.0/). 